\title{
HOSPITALITY INNOVATION STRATEGIES: AN ANALYSIS OF SUCCESS FACTORS AND CHALLENGES
}

\section{REFERENCE:}

Martin-Rios, C. \& Ciobanu, T. (2018). Hospitality Innovation strategies: An analysis of success factors and challenges.Tourism Management, 70: 218-229 


\title{
HOSPITALITY INNOVATION STRATEGIES: AN ANALYSIS OF SUCCESS FACTORS AND CHALLENGES
}

\begin{abstract}
Innovation in hospitality has attracted considerable interest, partly because its processes and activities are so diverse, and partly because its impact on performance is still a puzzle. This study proposes a comprehensive theoretical model that reviews combinations of technological and non-technological innovation and the interrelation between different innovation strategies that contribute to generating competitive advantages. Using data from 2010 and 2012 CIS, it empirically examines different innovation strategies, analyzes their role in organizational performance, and thoroughly researches sectoral variation in innovation strategies between hospitality and other service subsectors. Comparative analysis suggests that hospitality is the least innovative service activity. The findings also show that in hotels sales turnover is positively related only to complex innovation strategies that emphasize both technological and non-technological innovation. The study concludes that the level of innovation varies from sector to sector and that innovation strategies can have different effects on performance depending on the sector.
\end{abstract}

Keywords: Innovation strategy; Innovation management; Innovation practices; Non-technological innovation; Technological innovation; Hospitality; Service firms; Sales turnover; Performance; CIS data 


\section{INTRODUCTION}

Hotels are among the most competitive businesses in the world. Yet, as the specialized literature shows, productivity in the hotel industry is significantly lower than in all other sectors of the economy. One reason that may account for this discrepancy is that the hospitality industry is less likely to innovate than other service activities. This calls into question the role of traditional innovation practices in hospitality and reveals the importance of creating new strategic paradigms. The implementation of innovative practices has attracted considerable research efforts in the recent service and hospitality literature (Gomezelj, 2016; Martin-Rios \& Pasamar, 2018; Suoto, 2015; Tajeddini, Altinay \& Ratten, 2017). Yet, the literature in the hospitality field has barely paid attention to the development of more or less complex innovation strategies - the combination of technologydriven and non-technological forms of innovation (Karlsson \& Tavassoli, 2016; Tavassoli \& Karlsson, 2015) and, consequently, to the influence of innovation strategy on firm performance (for an interesting exception, see Nicolau \& Santa-Maria, 2013). Accordingly, more research is needed to analyze innovation strategies and the relationship between different strategies and organizational effectiveness in order to help hospitality companies build innovation capacity and enhance competitiveness and growth opportunities.

An innovation strategy is a requirement for succeeding in today's competitive environment. One important driver of this trend is the need for different forms of innovation to stay competitive and profitable, which could lead hospitality firms to search for and implement a variety of innovative solutions. An innovation strategy ensures that firms remain proactive, which may positively affect organizational competitiveness (Hjalager, 2010; Lin, 2013). Among the various types of innovation, previous research has identified the significant impact that less traditional forms of innovation have on service firm performance (Sandvik, Duhan \& Sandvik, 2014). By their very innovative nature, 
service firms, and expectedly hospitality firms, are inclined to broaden the scope of innovation and depart from the narrower technology-driven innovation dominant in manufacturing to also include non-technological forms of innovation (Carlborg, Kindström \& Kowalkowski, 2014; Černe, Kaše, \& Škerlavaj, 2016). Service firms draw here on the refined categorization of non-technological innovation as one that helps renewal within their core business model and internal processes. Nontechnological innovation can include novel approaches to commercialize firm assets (Gambardella \& McGahan, 2010; Martin-Rios \& Parga, 2016a), new managerial, structural or technical practices (Birkinshaw et al. 2008), and the adoption of new ways of organizing work processes, establishing alternative ways of managing employees (Tracey \& Way, 2011), and fostering internal and external relationships (Armbruster et al., 2008; Martin-Rios, 2014).

Hospitality firms and the broader service sector share certain features that influence their innovation strategy. But, as Castellacci's (2008) taxonomy shows, there are also big differences across the distinct service sectors. Given the vast diversity of firms in the service industry, different service companies innovate in different ways depending on, among a myriad of other factors, their subsector. As part of one of those sectors, the hotel industry implements innovation strategies that expectedly share similarities and differences with those of other service activities. An examination of the innovation strategies in each service activity contributes to identify sectoral distributions of the locus of strategic decision-making, variation in the propensity to innovate, and the strengths and weaknesses of different innovation paths. Building on Castellacci's sectoral taxonomy, this study reports aggregated data from two waves of the European Community Innovation Survey (CIS), 2010 and 2012, to assess variation in innovation strategies and activities and their impact on organizational performance. By means of multiple linear regression models, this paper explores the effect of a range of innovative activities across 90,896 European service firms, of them some 3.1\% (2,816 firms) in hospitality in 2010 and 2012. The harmonized survey questionnaire has been used extensively in 
service innovation (e.g. Hidalgo \& D’Alvano, 2014) and hospitality innovation (e.g. Hertog, Gallouj \& Segers, 2011).

The study presents an integrated conceptual framework that captures the complexity of the reality analyzing all service activities independently and contrasting them with hospitality. In doing so, the paper contributes to the developing literature on strategic innovation in hospitality. We believe that in this way this study makes a valuable contribution to the understanding of the complexity of the innovation path of hotel firms and their performance. As a second contribution, the study offers novel insights into the distinctive types of innovation configurations across all service activities and suggests lessons that can be learned from best practices.

\section{LITERATURE REVIEW}

The study's conceptual model addresses innovation strategies and activities in shaping performance of firms in the multi-sectoral service industry, with particular focus on hospitality (see Figure 1). This model proposes that different strategies and forms of innovation have different impacts on firms' financial performance, defined as the market sales of goods and services. However, as the next section shows, a lack of research in this area means that there are doubts regarding the benefits of each innovation initiative for hospitality firms.

Insert Figure 1 here

\section{Innovation strategy and categories of innovation}

Firms have a wide range of preferences when it comes to choosing their innovation strategy. Since the majority of firms have limited resources and innovation capabilities, they face several innovation 
choices, which are included in Schumpeter's four types of innovation (process, product, marketing, and organizational) plus various combinations of these four types. The latest edition of the OECD Oslo Manual (Mortensen \& Bloch, 2005: 46) defines innovation as "the implementation of new or significantly improved product (good or service), or process, a new marketing method, or a new organizational method in business practices, workplace organization or external relations." The common service innovation categorization distinguishes between these four types of innovation (Khan \& Khan, 2009; Gomezelj, 2016; Hjalager, 2010; Nieves \& Segarra-Cipres, 2015).

Product/service innovation refers to the development and introduction of a new service. Service innovation in hotels and the service sector at large employs new knowledge and technologies, or new combinations of existing knowledge and technologies. These innovations are expected to provide service firms with a competitive advantage via the technological novelty of the service (Evangelista \& Vezzani, 2010). Typically, the impact of service innovation is similar to the impact of goods innovation (Gunday et al., 2011; Lei, 2012). Both of them aim at decreasing costs, creating new activities and opening new pathways to markets (Lehtinen \& Järvinen, 2015). Research in hotels shows that the introduction of new services can vary in degrees of complexity but, for the most part, entails the adoption or use of innovations generated externally (Scaglione, Schegg \& Murphy, 2009).

Process innovation includes the application of a new or significantly improved service delivery method. It aims to either decrease the unit costs of delivery or to increase the quality of the service (Mortensen \& Bloch, 2005). Process innovations are introduced to attain specific goals, for example to better define and improve repeated activities associated with the delivery of a particular service (Tether, 2005). In contrast to the introduction of new services, which are considered to have a clear positive financial return, Fagerberg et al. (2004) suggest that the effect of process innovation on performance is ambiguous. Often, hotel companies develop their own process innovations, which 
require that both service innovations and organizational innovations to be taken into account (Hertog et al., 2011; Nieves, Quintana \& Osorio, 2014; Orfila-Sintes \& Mattsson, 2009).

Organizational innovation is conceptualized as the implementation of a new organizational method in the firm's business practices, workplace organization or external relations" that intends to improve the effectiveness or performance of the adopting firm (Mortensen $\&$ Bloch, 2005: 51). It is the less discrete, more intangible and organization-specific part of service innovations (Armbruster et al., 2008; Birkinshaw et al., 2008). This is an important source of innovation with a potential impact on the adaptability of the firm to changing market conditions (Martin-Rios \& Parga 2016a, 2016b). Hospitality research has studied and modeled the antecedents that enhance the likelihood of organizational innovation activities in a firm. Among these antecedents, adaptation of management style will be a determining factor in fostering innovation initiatives, provided that managers have the right skills and capabilities to handle such situations (Martinez-Ros \& Orfila-Sintes, 2012; Nieves, Segarra-Cipres, 2015).

Marketing innovations are the implementation of a new marketing method not formerly used by the firm, including "significant changes in promotion or pricing, product placement, product design or packaging" (Mortensen \& Bloch, 2005: 49). These innovations focus on customer needs, opening new markets, or repositioning a company's product with the intent to increase sales. Research shows that successful marketing innovation helps service firms to strengthen their competitive strategy (Line \& Runyan, 2012; Scaglione et al., 2009).

In terms of innovation strategy, service and process innovations are closely related to technological developments (Gunday et al., 2011). In that sense, ICT plays a prevalent role in hotels' service and process innovation. Moreover, organizational and marketing innovations are broadly defined as non- 
technological innovations (Černe, Kaše, \& Škerlavaj, 2016). Current innovation research has departed from a limited technology-driven innovation paradigm to identify and include forms of nontechnological innovation. This has rendered the innovation management highly unpredictable and has brought about marked changes in the service industry's approach to innovation. In their recent work, Karlsson and Tavassoli (2016) explored the question of what basic types or innovation or what combination of types of innovation firms should introduce. They distinguished between sixteen innovation strategies, including the four simple types of innovations (process, product, marketing, and organizational) plus various more or less complex combinations of these four types. In a related study, these authors investigated and found support for the existence of a high degree of persistent behavior in innovation strategy (Tavassoli and Karlsson, 2015). In terms of innovation behavior over time, the higher degree of persistent behavior (i.e. effect of previous innovation on future innovation) is strongest among product innovators (Tavassoli \& Karlsson, 2015). In general, innovative firms tend to favor simple or complex strategies with a recurring set of innovation initiatives, and their strategic decisions prevail over time. The research to date, although promising, requires additional evidence to determine the specificities of innovation strategies in hospitality and the service sector at large.

\section{Sectoral differences on innovation}

Innovation in the service sector has gained prominence over recent years in parallel with the recognition of its singularity (Castellacci, 2008; Gallouj, 2002; Gallouj \& Weinstein, 1997; Gomezelj, 2016; Miles, 2005; Miozzo \& Soete, 2001; Tether, 2005). To understand the variety of innovation patterns and strategies in different service activities (Chang, Linton, \& Chen 2012), several classifications have been proposed, of which the most influential is the taxonomy developed by Castellacci (2008). Service firms are classified in three patterns of innovation as knowledge intensive, 
infrastructural and personal or supplier-dominated services. This integrated taxonomy combines manufacturing and service industries, drawing on Pavitt's (1984) seminal typology—of supplierdominated firms, specialized suppliers of capital goods, science-based firms, and scale-intensive firms - to put forward sectoral patterns of innovation. In this study, service firms and hospitality firms are classified in these service blocks to facilitate comparison between their innovation strategies and practices (see Figure 2). Although the innovation pattern of hotels is SDS (Castellacci, 2008, OrfilaSintes el al., 2005), for the purpose of this study it is classified into a distinct category.

Insert Figure 2 here

Knowledge-intensive business services (KIBS) include providers of specialized knowledge, such as research and development, consultancy, architecture, design, engineering and technical services (Freel, 2006). Companies in this category create, manage and provide complex technological knowledge, where human capital rather than physical inputs constitute the critical capability for generating a competitive advantage (Grant, 1996). KIBS play an increasingly dynamic and pivotal role in new knowledge-based economies. As a result, KIBS need to constantly upgrade and renew their own knowledge base. To do so, KIBS are expected to adopt a broad, complex portfolio of innovation initiatives (Rodriguez \& Camacho, 2010). Moreover, infrastructural or supporting infrastructure services (SIS) produce intermediate services which are not intended for personal consumption. These include providers of distributive and physical services including large-scale, standardized service firms (e.g. transport or wholesale trade) and providers of network infrastructure services, comprising customized and less standardized service suppliers (e.g. finance, real estate and telecommunications) (Miles, 2008). Supporting services have a limited ability to create new knowledge and capabilities internally. Hence, their innovation activities are based on the acquisition of machinery, equipment, and technological knowledge created elsewhere in the economic system 
(Malerba, 2002). Finally, supplier-dominated services (SDS) or personal services include massservice companies with a large customer base, but limited client contact and limited client specific judgement (Miozzo \& Soete, 2001). Examples of SDS include personal services, hotels and restaurants, and retail trade. Research suggests that supplier-dominated firms are characterized by low levels of formal innovation and they rely on the purchase of goods and interaction with suppliers and users for their innovation (Aas et al., 2015).

Hospitality is formally part of SDS, yet existing research shows some distinct characteristics of the activity; for example, a productivity gap between hospitality firms and other SDS (Gomezelj, 2016; Sharma et al., 2016). Hospitality is characterized as a labor-intensive, largely seasonal, cost-driven industry with less inclination to $R \& D$ and large investments in technological innovation as may be the case in other service activities. Yet there is a dearth of comparative studies between hospitality and different service sectors (for an exception, see Sharma et al., 2016). The literature on innovation in hospitality is scarce, particularly in terms of empirical evidence (Hjalager, 2010; Gomezelj, 2016). It is important to note that Gomezelj's (2016) recent literature review yields 152 works devoted primarily to innovation in hospitality, whereas a search on Google Scholar of articles on, for example, innovation management in biotechnology offers 7,800 articles since 2011 and, over 17,000 for the 2000-2015 period. Still, several authors suggest that social and sustainability challenges, global competition, technological advancement and changing customer demands may well force hospitality firms to step up innovation (Hjalager, 2009; Hertog et al., 2009; Orfila-Sintes \& Mattsson, 2010; Tajeddini, 2010).

\section{Innovation strategies and performance}


The broadening of decision-making for innovation processes in the service sector has become manifest over the past decade (Lin, 2013). Research has begun to test whether configurations of innovation practices have a differentiated impact on firm results (Evangelista \& Vezzani, 2010). Firms often make strategic decisions to innovate, resulting in innovation configurations of one or more innovation actions. The introduction of new services often requires firms to adopt new service processes, organizational practices, service designs, promotion and placement and so on. In that sense, a firm can choose to implement none or any of the four types of innovation-i.e. product, process, organizational and marketing, or a combination of these four types. Therefore, a firm can have one of the sixteen possible innovation strategies at a given point in time (Karlsson \& Tavassoli, 2016). Implementation of one of the four types of innovation represents a simple innovation strategy whereas a combinations of these four types of innovation represents a complex strategy. Coordination of innovation decisions can result in complex innovation strategies. A complex strategy is formed, for example, by adopting all technology-derived innovations (product and process) or all nontechnological innovations (organizational and marketing). Finally, a hybrid complex innovation strategy results from combining one or more technology-derived innovations (product and process) and non-technological innovations (organizational and marketing).

In their study of Swedish manufacturing firms, Karlsson and Tavassoli (2016) observed that firms chose from all sixteen strategies. More than half of the companies in the study chose a complex innovation strategy. Yet, their cross-sectional study does not identify which service innovation strategy or strategies were implemented. It is expected that service firms in different sectoral activities focus on different innovation strategies (or combinations thereof) at the same time. An examination of the various configurations of technological and non-technological innovation activities in each service activity contributes to identify the strengths and weaknesses of different innovation paths. 
Little previous research has analyzed the dynamics of innovative activities on services. For example, Chang, Linton and Chen (2012) have applied Miozzo and Soete's service regime taxonomy on Taiwanese service firms. These authors conclude that service firms have patterns of innovation that are best described as loosely coupled systems with diversified sources of innovation. Given that KIBS, SIS and SDS face unique external forces and internal characteristics (Castellacci, 2008), it is expected that these factors influence their innovative strategy and, in turn, their innovation activity. Moreover, to better understand the implications of innovation for hotels, it is useful to start by asking whether their innovation strategies are different from those in other service sectors. The review of past research has revealed differences between hospitality innovation and other service activities. Therefore, the following hypotheses are proposed:

Hypothesis 1a. The existence of sectoral differences exert a positive influence in the variety of innovative strategies and patterns within service firms.

Hypothesis 1b. The existence of sectoral differences exert a positive influence in the variety of innovative strategies and patterns between hospitality firms and other service firms.

The existence of a great variety of innovative strategies would help explain similarities and differences between service sectors with respect to the business success factors. Yet, studies on sectoral differences in the relationship between innovation strategy and firm performance are limited. For example, Szczygielski, Grabowski and Woodward (2017) have observed a positive relationship between innovation and employment growth in service firms in Poland. Chamberlin, Doutriaux and Hector (2010) have looked at a wide set of service sectors and have observed a high degree of heterogeneity in business results between innovative and non-innovative firms. None of these works investigate the influence of innovation strategy on firm outcomes. There is an expectation that internal variability of innovation types will lead to differences in organizational performance, defined as the 
market sales of goods and services. Service firms adopting complex innovation strategies could obtain better sales turnover. Alternatively, simple strategies could be associated with lower firm turnover. In response to Karlsson and Tavassoli's (2016) call for more empirical research on the effect of various choices of innovation strategies on firm performance, this study proposes to test the following hypothesis:

Hypothesis 2. Utilization of complex innovation strategies (technological and non-technological sources of innovation) positively affects sales turnover within service firms.

The hotel industry implements innovation strategies that expectedly share similarities and differences with those of other service activities. In this sense, a number of authors have looked at the link between innovation and financial performance in hotels. For example, Grissemann, et al. (2013) observed that new products and services have a positive impact on hotels' financial performance. Hjalager (2010) further state that the manager's perception of hotel performance is positive and significantly influenced by innovation. Despite the pervasiveness of innovation in the hospitality sector, there is a surprising lack of empirical work on the relationship between innovation strategy and results. To date, there is a dearth of studies on innovation strategy in hospitality, whether these firms are likely to pursue more hybrid type of complex strategies that rely on combinations of technological and non-technological innovation, and furthermore, on the relationship between strategy and market sales of goods and service. The lack of research linking innovation strategy and financial performance leads to the formulation of the following hypothesis:

Hypothesis 3. Utilization of complex innovation strategies (technological and non-technological sources of innovation) positively affects sales turnover within hospitality firms.

\section{METHODS}




\section{Sample and Procedure}

Statistical analysis is based on responses obtained from the EU's anonymous micro data from the Community Innovation Survey - CIS 7 (which covered years 2008-2010) and CIS 8 (2010-2012). The data collection took place in 2011 and 2013, and the results were published in October 2012 and 2014. It is based on a common questionnaire and methodology, which refers back to the Oslo Manual (2005) to collect information on innovation in businesses in EU member states. The survey has 14 participating countries (13 EU member states and Norway) reporting their results for the reference periods. The target population of the CIS 2010 and 2012 includes small, medium, and large companies in all sectors of the economy. To extrapolate the results to the whole target population, weighting factors are established based on the proportion of the number of companies or employees in each layer of the frame population. The CIS is comprehensive in terms of the range of questionnaire items, including direct measures of innovation performance and a wide variety of factors influencing innovation. In that sense, CIS data source makes it possible to build a dataset that is particularly suitable for implementing a comprehensive statistical analysis of both hotels' and service firms' adoption of innovation strategies and the relationship between innovation strategy and firm's sales turnover. Statistical analyses are performed in a cross-sectional way by pooling responses from the two time periods 2008-2010 and 2010-2012.

In accordance with the Castellacci (2008) taxonomy, four categories of activities are proposed: (1) AKP (advance knowledge providers), (2) MPG (mass production goods), (3) SIS (supporting infrastructure services), and (4) PGS (personal goods and services). Within them, service firms are classified in KIBS (knowledge intensive business services), SIS (supporting infrastructure services) and SDS (supplier-dominated services) (Figure 2). The survey data collected in CIS 2008-2010 and 2010-2012 comprises 193,947 enterprises, including innovating and non-innovating companies. Of those, 98,041 (50.6\%) are service firms (Table 1). After applying Castellacci's taxonomy to the 
service firms that responded to CIS 7 and CIS 8, they are fairly well distributed across all three clusters: KIBS (20.4\%), SIS (48.1\%) and SDS (31.5\%). Firms in the accommodation and food service activities (NACE Code 55 -56) make up 3.3\% of the total sample.

Insert Table 1 here

\section{Measures}

\section{Dependent variable: Sales turnover}

To analyze the effects of innovation on firm performance existing research has used financial performance measures (i.e. sales, profit, or stock prices) and non-financial performance measures, such as innovation performance (e.g. patents, new processes and products). For the purpose of this study we adopt the former perspective. In line with previous research (Belderbos, Carree \& Lokshin, 2004; Faems et al., 2005; Nieto \& Santamaria, 2007), the "total turnover" index reported by each firm was defined as the dependent variable. We measured firm's turnover in 2010 and 2012 as the market sales of goods and services, including all taxes except VAT, for each of the preceding three-year period 2008-2010 and 2010-212. The analyses incorporate the natural logarithm of $1+$ the total turnover variation for the three-year period in order to obtain a normal distribution.

\section{Independent variables: innovation strategies}

Product, process, organizational and marketing innovations are defined as independent factors and predictors. In line with recent research using CIS data, we do not consider new services and new goods separately (Asikainen, 2015; Szczygielski et al., 2017). In the case of service firms, it is hard to determine what the goods offered by such firms could be. Therefore, the present study considers the more general category of product innovations. The four innovation practices are represented by a dummy variable that took the value of 1 if the firm introduced any product, process, organizational or marketing innovation during each of the three-year period 2008-2010 and 2010-2012, and zero 
otherwise. Previous studies have used the four innovation types as proxies for innovation-level variables (Karlsson \& Tavassoli, 2016; Nicolau \& Santa-Maria, 2013; Tavassoli \& Karlsson, 2015). Table 2 shows the items used to operationalize each innovation type, according to Oslo Manual and Eurostat's definitions (2010).

Insert Table 2 here

General innovation level is defined as the sum of all innovation types used in each company. It is important to note that the general innovation level does not take into consideration the qualitative aspect of how many different innovation initiatives a firm takes within one type of innovation practice (e.g. four different marketing innovation actions are still counted as 'one' marketing innovation practice). Subsequently, certain service sectors (e.g. hospitality) might have a very low general innovation score, but have a very high score within or for one certain subcategory of innovation. Hence, the internal variability of innovation initiatives across sectoral activities is not investigated in the present study. Regarding innovation strategy, three generic innovation strategies are defined: simple strategy - when the company uses only one of the four innovation practices; complex strategy - when the company implements bundles of technological or non-technological innovation practices; and hybrid complex strategy, which corresponds to the various combinations of technological or nontechnological innovation practices.

\section{Control variables}

Previous literature sheds light on the important relationship between company size and innovation management. In general, large firms tend to have advantages in reaching their innovation goals when compared with small firms: to the degree that they have a larger knowledge-base and resources to attenuate uncertainty (Nieto \& Santamaria, 2010). Conversely, small firms have been credited with 
increasing flexibility in structure (Chen \& Hambrick, 1995) and managing knowledge assets and intangibles (Martin-Rios \& Erhardt, 2017), which might lead to higher dynamism when managing the informal type of innovative activities. Thus, we used firm size as a control variable. Table 2 shows how company size has been classified. Additionally, according to the European Commission (2016), there are large differences in terms of innovation levels across European countries. In order to account for these differences, the second control variable introduced is the country where the firm is located.

\section{Data Analysis}

Univariate ANOVA analysis was conducted to compare the general innovation level in KIBS, SIS, SDS sectors, as well as between SDS and hospitality services. The control factors were country and company size variables. To determine the simple and mixed effects of all innovation types on sales turnover, data from 90,896 service firms were subjected to multiple sector (and hospitality-specific) linear regression analyses. The regression models were developed as follows: Model $1-$ control variables (country, company size); Model 2 - simple innovations; Model 3 - complex technological innovations; Model 4 - complex non-technological innovations; Model 5 - hybrid 2 innovations; Model 6-hybrid 3-4 innovations; Model 7 - all innovations. All statistical analyses were performed with SPSS (24.0).

\section{Results}

Table 3 illustrates the percentage of innovation levels for all innovation types and their subcategories within each of the three service sectors and hospitality.

Insert Table 3 here 
As described in Table 3, there are sectoral differences in innovation level. $40.3 \%$ of firms used at least one innovation strategy. The most innovative sector is KIBS where $55.8 \%$ of firms are considered to be innovative, followed by SDS (38.3\%) and SIS (35.9\%). In the hospitality sector, only $29 \%$ of firms used an innovative strategy. Regarding the appetite for innovation, univariate ANOVA results on general innovation levels revealed a significant effect of service industry type ( $F$ $\left.(3,97887)=49.41, p<.001, \eta_{p}^{2}=.001, d=1\right)$. Pairwise comparisons indicated that, on average, the KIBS sector $(M=2.14, S E M=.02)$ develops significantly more innovative practices when compared to SIS $(M=1.28, S E M=.01), \operatorname{SDS}(M=1.24, S E M=.01)$ and Hospitality $(M=.89, S E M=.03)$ sectors. Thus, the general innovation level in hospitality firms is the lowest among the service firms. Additionally, the modulatory effects of country $\left(F(13,97887)=160.11, p<.001, \eta_{p}^{2}=.002, d=1\right)$ and company size $\left(F(5,97887)=150, p<.001, \eta_{p}^{2}=.008, d=1\right)$ were significant.

For each service sector, we conducted multiple regression models to examine the effects of the simple and complex innovation strategies on the log transformed sales turnover variable. Table 4 to Table 7 show the effects of the innovation strategies have upon $(\ln )$ sales turnover in KIBS, SIS, SDS and hospitality sectors. In all activities, results revealed that the country and company size were significant predictors of total sales turnover regardless of the innovation strategies. The effects of country and firm size variables were highly relevant (KIBS: $\operatorname{Adj} R 2=48 ; p<.001 ; \operatorname{SIS}: \operatorname{Adj} R 2=40$; $p<.001 ; \operatorname{SDS}: \operatorname{Adj} R 2=40 ; p<.001 ;$ Hospitality; $\operatorname{Adj} R 2=42 ; p<.001)$

Table 4 shows that in the KIBS sector all the innovation strategies included in the six models are positive predictors of total sales turnover except non-technological complex innovations. Moreover, marketing innovation was a significant negative predictor $(\beta=-.18, p<.001)$. Overall, in the KIBS sector, all innovation strategies explained $1.1 \%$ of the general variance in total sales turnover (Model $7: \Delta R 2=.011 ; p<.001)$. 
Regarding the effects of the innovation strategies in SIS industries, results revealed that all the innovation strategies were significant positive predictors in all models. The results of Model 7 indicate that in the SIS sector innovation strategies altogether had the biggest impact $(2.6 \%)$ on $(\ln )$ sales turnover $(\Delta R 2=.026 ; p<.001)$ when compared to the other service sectors.

\section{Insert Table 5 here}

The regression models of the SDS sector are shown in Table 6. Model 2 (simple innovations), Model 4 (complex non-technological innovations), Model 5 (complex hybrid 2 innovations) and Model 7 (all innovations) illustrate that organizational innovation alone and combined with product innovation was not a significant predictor of firm's sales turnover. Likewise, Model 5 shows that the hybrid strategy between marketing and product innovation was not a significant predictor either. These results notwithstanding, all the other innovation strategies in the SDS sector were found to be positive predictors of $1.3 \%$ of total sales turnover (Model $7: \Delta R 2=.013 ; p<.001)$.

\section{Insert Table 6 here}

Table 7 shows the effects of innovation strategies in the hospitality sector. Overall, innovation strategies explained $1.2 \%$ of the (ln) sales turnover over the two three-year period analyzed (Model $7: \Delta R 2=.012 ; p<.001)$. Unlike the previous service sectors and of relevance for the present study, the effects of innovation strategies were different in the hospitality sector. Simple innovations, complex technological and non-technological innovations were found to be non-significant predictors 
of sales turnover (Models 2, 3, 4, 7). Conversely, the majority of the complex hybrid innovation strategies were found to be positive predictors of firm's sales turnover. Results indicated that hybrid strategies between product-process-marketing $(\beta=1.03 ; p<.001)$, product-process-organization $(\beta=1.03 ; p<.01)$, product-organization $(\beta=.73 ; p<.001)$ and process-product-organizationmarketing $(\beta=.68 ; p<.001)$ were the most relevant predictors of total market sales.

Insert Table 7 here

\section{Discussion}

In the last decade, interest in hospitality innovation has grown markedly. Research has analyzed sources and dimensions of innovation. Yet, the reasons behind the adoption of innovation strategies in service and hospitality firms are only marginally and indirectly addressed in hospitality research. Therefore, it is to research on hospitality innovation and effectiveness that this paper intends to contribute. In doing so, it provides a comprehensive analysis of the relationship between technologydriven innovation, the less traditional, non-technological innovation and organizational effectiveness by means of an empirical study of sectoral differences in strategic innovation patterns in a variety of EU countries. Moreover, it underscores the crucial role of innovation strategies in fostering competitive advantages for hospitality firms.

This study explores the sectoral differences in innovation levels and innovation complexity according to innovation strategies. Existing research suggests that service sectors have different general innovation levels and that certain innovation types are more successful than others (Castellacci, 2008; Enz, 2012). The hospitality and strategic innovation literature increasingly recognizes that a combination of technology-driven and non-technological initiatives is a key element of a successful 
innovation strategy (Hjalager, 2010; Martin-Rios \& Parga, 2016b). Studies in the service sector and, particularly, in hospitality activities proved that innovation can have a positive impact on firm performance (Martin-Rios \& Pasamar, 2018; Orfila-Sintes \& Mattsson, 2009). However, few sectoror hospitality-specific studies have been devoted to explaining the prevalence of simple and complex innovation strategies and their link to firm performance.

Drawing on CIS 7 and CIS 8 data, it was found that general innovation levels vary among the service sub-sectors. Moreover, it was confirmed that KIBS have the highest mean score in innovation level and SIS the lowest one. A significant difference was also found between hospitality and SDS. In terms of sectoral differences in innovation strategies, knowledge-intensive services pursue complex innovation strategies in which combinations of product, process, organizational and marketing innovations are complementary. These findings are consistent with existing research on sectoral differences. For example, Amara, Landry and Doloreux (2009) observed that KIBS tend to implement combinations of technological and non-technological innovations.

Moreover, SIS firms benefit from simple and complex innovation strategies, with higher results when they use a hybrid, complex innovation approach involving product, process, organizational, and marketing innovation. Prior studies have shown that SIS firms employ process innovation (especially technological implementations coming from other sectors) to increase workflow processes and service quality (Castellacci, 2008). For example, Roberts and Amit's (2003) analysis of the adoption of product and process innovations in the retail banking industry concluded that "the vast majority of observed innovative activity was based on ideas sourced from outside the focal firm, and that innovations diffused very quickly across competing banks" (p.107). 
Finally, supplier-dominated services (SDS) have limited ability to create new knowledge and capabilities internally. Hence, their innovation activities are based on the acquisition of machinery, equipment, and technological knowledge created elsewhere in the economic system (Malerba, 2002). For product and process innovation SDS firms need to access external information and knowledge sources, which include links to suppliers, consulting firms, customers, competitors and providers of technological knowledge and scientific knowledge (like universities and R\&D firms). In SDS firms, organizational innovations have no direct effect on market sales turnover. Scaling up nontechnological innovations will need to be combined with certain technological innovations. Hybrid innovation strategies are connected with higher sales turnover.

Results suggest that the patterns of innovation in hospitality differ from other sectoral activities. For hospitality and $\mathrm{F} \& \mathrm{~B}$ forms, organizational effectiveness is underpinned by a more complex pattern of innovation that emphasizes hybrid strategies. For example, hospitality-specific innovation strategies lead to greater market sales turnover, but solely if they are combined with the implementation of a new or significantly improved organizational activity for the processes (e.g., new work practices). Improved methods of producing services (e.g., new food production system) or improved distribution/logistics (e.g., use of a new distribution channel) in isolation do not affect sales turnover. Consistent with previous CIS-based studies, sales performance is associated with a greater share of innovative activities in the firm's portfolio (Szczygielski et al., 2017). In regard to sectorspecific innovation strategies, complex strategies in KIBS, SIS and SDS significantly predict change in sales turnover. In the case of hospitality firms, only hybrid complex innovation strategies, specifically the combination of product/process innovation with organizational or marketing innovation, are able to significantly predict total market sales turnover. A reason for that is the decisive role played by both technological and non-technological innovation initiatives. Within the research on innovation there has always been an emphasis on the role played by technological 
innovations to boost productivity. More recently, research has increasingly emphasized that innovation performance at the organizational level may also be a function of how hospitality firms are managed (Souto, 2015). This relates to the synergies created between different types of innovations (Mattsson \& Orfila-Sintes, 2013) and highlights the increased importance of nontechnological innovations in services (Martin-Rios \& Parga, 2016b).

\section{Practical Implications}

For managers in hospitality services this study has a range of important implications. Firms should consider implementing a combination of innovation types (service, process, marketing, and organizational) that yield an increase in performance. Specifically, hospitality professionals should focus on bundles of innovative initiatives, for example, new or improved supporting activities for processes in combination with new methods for service placement and sales channels. Any such combination needs to be carefully selected according to a formally designed innovation strategy. As the statistical results show, the simple accumulation of innovation activities does not yield positive outcomes. Finally, there appear to be significant differences between and within sectoral activities. It is not possible to simply uproot innovation best practices from other service industries and plant them in the hotel industry. That is why hospitality professionals should carefully select and combine innovation types and not blindly increase the volume of innovations.

\section{Limitations and Conclusion}

Shortcomings of CIS-based studies resulted in several limitations. Innovation results are moderated by country. Within the industry of hospitality services, a limited number of countries were present, therefore an increased number of participating countries would make the results more robust. Third, in order to offer a more robust model, output variables other than total market sales of goods and services should be included in the model. Future research will benefit from examining multiple 
interactions between different innovation strategies and their effect on different financial and nonfinancial performance measures, for example, innovation performance. Finally, the large impact of firm size, which was only briefly discussed, needs to be further analyzed to come up with solutions for smaller companies whose innovation activities might yield a smaller effect on firm performance.

In conclusion, despite the pervasiveness of innovation in the service and hospitality industry, surprisingly little is known theoretically and empirically about the determinants of service firms' innovation strategies. Research on hospitality innovation needs to be expanded and there is a need for better empirical and quantitative evidence (Gomezelj, 2016; Hjalager, 2010). Only a handful of studies have been devoted to disentangle the interaction between innovation strategy, forms of innovation and organizational performance. Furthermore, there is still a lack of knowledge on the effects of less-traditional innovation initiatives on firm results. This paper aims to fill these gaps to better understand the relationship between innovation strategy and total turnover in the hospitality industry, and so contribute to the extant literature on the subject. 


\section{References}

Aas, T. H., Breunig, K. J., Hydle, K. M., \& Pedersen, P. E. (2015). Innovation management practices in production-intensive service firms. International Journal of Innovation Management, 19(05), 1550055, 1-28. https://doi.org/10.1142/S1363919615500553

Amara, N., Landry, R., \& Doloreux, D. (2009). Patterns of innovation in knowledge-intensive business services. The Service Industries Journal, 29(4), 407-430. https://doi.org/10.1080/02642060802307847

Armbruster, H., Bikfalvi, A., Kinkel, S., \& Lay, G. (2008). Organizational innovation: The challenge of measuring non-technical innovation in large-scale surveys. Technovation, 28, 644-657. https://doi.org/10.1016/j.technovation.2008.03.003

Asikainen, A.L. (2015). Innovation modes and strategies in knowledge intensive business services. Service Business, 9(1), 77-95. DOI 10.1007/s11628-013-0219-5

Belderbos, R., Carree, M., \& Lokshin, B. (2004). Cooperative R\&D and firm performance. Research Policy, 33(10), 1477-1492. https://doi.org/10.1016/j.respol.2004.07.003

Birkinshaw, J., Hamel, G., \& Mol, M. (2008). Management innovation. Academy of Management Review, 33, 825-845. https://doi.org/10.5465/amr.2008.34421969

Carlborg, P., Kindström, D., \& Kowalkowski, C. (2014). The evolution of service innovation research: A critical review and synthesis. The Service Industries Journal, 34(5), 373-398.

https://doi.org/10.1080/02642069.2013.780044

Castellacci, F. (2008). Technological paradigms, regimes and trajectories: Manufacturing and service industries in a new taxonomy of sectoral patterns of innovation. Research Policy, 37(6-7), 978-994. doi:10.1016/j.respol.2008.03.011

Černe, M., Kaše, R., \& Škerlavaj, M. (2016). Non-technological innovation research: evaluating the intellectual structure and prospects of an emerging field. Scandinavian Journal of Management, 32(2), 69-85. https://doi.org/10.1016/j.scaman.2016.02.001

Chamberlin, T., Doutriaux, J., \& Hector, J. (2010). Business success factors and innovation in Canadian service sectors: An initial investigation of inter-sectoral differences. The Service Industries Journal, 30(2), 225-246. https://doi.org/10.1080/02642060802120174

Chang, Y.C., Linton, J.D., \& Chen, M.N. (2012). Service regime: An empirical analysis of innovation patterns in service firms. Technological Forecasting and Social Change, 79(9), 1569-1582. https://doi.org/10.1016/j.techfore.2012.05.017

Chen, M. J., \& Hambrick, D. C. (1995). Speed, stealth, and selective attack: How small firms differ from large firms in competitive behavior. Academy of Management Journal, 38(2), 453-482. https://doi.org/10.5465/256688

Enz, C. A. (2012). Strategies for the implementation of service innovations. Cornell Hospitality Quarterly, 53(3), 187-195. https://doi.org/10.1177/1938965512448176

European Commission (2016). European Innovation Scoreboard 2016. Maastricht: MERIT 
Eurostat (2010). The Community Innovation Survey 2010. Retrieved from:

http://ec.europa.eu/eurostat/documents/203647/203701/CIS Survey form 2010.pdf/b9f2c70e-0c464f82-abeb-c7661f1f2166

Evangelista, R., \& Vezzani, A. (2010). The economic impact of technological and organizational innovations. A firm-level analysis. Research Policy, 39(10), 1253-1263.

https://doi.org/10.1016/j.respol.2010.08.004

Faems, D., Van Looy, B., \& Debackere, K. (2005). Interorganizational collaboration and innovation: Toward a portfolio approach. Journal of Product Innovation Management, 22(3), 238-250. https://doi.org/10.1111/j.0737-6782.2005.00120.x

Fagerberg, J., Mowery, D.C., \& Nelson, R.R. (2004). The Oxford Handbook of Innovation. Oxford University Press: London.

Freel, M. (2006). Patterns of technological innovation in knowledge-intensive business services. Industry \& Innovation 13(3): 335-358. https://doi.org/10.1080/13662710600859157

Gallouj, F. (2002). Innovation in services and the attendant old and new myths. The Journal of SocioEconomics, 31(2), 137-154. https://doi.org/10.1016/S1053-5357(01)00126-3

Gallouj, F. \& Weinstein, O. (1997). Innovation in services. Research Policy, 26(4-5), 537-556. https://doi.org/10.1016/S0048-7333(97)00030-9

Gambardella, A., \& McGahan, A. M. (2010). Business-model innovation: General purpose technologies and their implications for industry structure. Long Range Planning, 43(2-3), 262-271.

https://doi.org/10.1016/j.1rp.2009.07.009

Gomezelj, D. O. (2016). A systematic review of research on innovation in hospitality and tourism. International Journal of Contemporary Hospitality Management, 28(3), 516-558. https://doi.org/10.1108/IJCHM-10-2014-0510

Grant, R. (1996). Toward a knowledge-based theory of the firm. Strategic Management Journal, 17(S2): 109-122. https://doi.org/10.1002/smj.4250171110

Grissemann, U., Plank, A., \& Brunner-Sperdin, A. (2013). Enhancing business performance of hotels: The role of innovation and customer orientation. International Journal of Hospitality Management, 33, 347356. https://doi.org/10.1016/j.ijhm.2012.10.005

Gunday, G., Ulusoy, G., Kilic, K., \& Alpkan, L. (2011) Effects of innovation types on firm performance. International Journal of Production Economics, 133(2), 662-676.

https://doi.org/10.1016/j.ijpe.2011.05.014

Hertog, P.D., Gallouj, F., \& Segers, J. (2011). Measuring innovation in a 'low-tech' service industry: the case of the Dutch hospitality industry. The Service Industries Journal, 31(9), 1429-1449. https://doi.org/10.1080/02642060903576084

Hidalgo, A., \& D'Alvano, L. (2014). Service innovation: Inward and outward related activities and cooperation mode. Journal of Business Research, 67(5), 698-703.

https://doi.org/10.1016/j.jbusres.2013.11.030 
Hjalager, A. M. (2010). A review of innovation research in tourism. Tourism Management, 31(1), 1-12. https://doi.org/10.1016/j.tourman.2009.08.012

Karlsson, C., \& Tavassoli, S. (2016). Innovation strategies of firms: What strategies and why?. The Journal of Technology Transfer, 41(6), 1483-1506. DOI: 10.1007/s10961-015-9453-4

Khan, M., \& Khan, M.A. (2009). How technological innovations extend services outreach to customers: The changing shape of hospitality services taxonomy. International Journal of Contemporary Hospitality Management, 21(5), 509-522. https://doi.org/10.1108/09596110910967773

Lehtinen, U., \& Järvinen, R. (2015). The role of service characteristics in service innovations. Nordic Journal of Business, 64(3), 3-15.

Lin, L. (2013). The impact of service innovation on firm performance. The Service Industries Journal, 33(15/16), 1599-1632. https://doi.org/10.1080/02642069.2011.638712

Line, N. D., \& Runyan, R. C. (2012). Hospitality marketing research: Recent trends and future directions. International Journal of Hospitality Management, 31(2), 477-488.

https://doi.org/10.1016/j.ijhm.2011.07.006

Malerba, F. (2002). Sectoral systems of innovation and production. Research Policy, 31(2), 247-264. https://doi.org/10.1016/S0048-7333(01)00139-1

Martínez-Ros, E., \& Orfila-Sintes, F. (2012). Training plans, manager's characteristics and innovation in the accommodation industry. International Journal of Hospitality Management, 31(3), 686-694. https://doi.org/10.1016/j.ijhm.2011.09.004

Martin-Rios, C. (2014). Why do firms seek to share human resource management knowledge? The importance of inter-firm networks. Journal of Business Research, 67, 190-199.

http://dx.doi.org/10.1016/j.jbusres.2012.10.004

Martin-Rios, C., \& Erhardt, N. (2017). Small business activity and knowledge exchange in informal interfirm networks. International Small Business Journal, 35(3), 285-305.

https://doi.org/10.1177/0266242616667540

Martin-Rios, C., \& Parga-Dans, E. (2016a). The early bird gets the worm, but the second mouse gets the cheese: Non-technological innovation in creative industries. Creativity and Innovation Management, 25, 6-17. https://doi.org/10.1111/caim.12131

Martin-Rios, C. \& Parga-Dans, E. (2016b). Service response to economic decline: Management innovation as enabler of organizational renewal. Journal of Business Research, 69(8): 2890-2900. https://doi.org/10.1016/j.jbusres.2015.12.058

Martin-Rios, C., \& Pasamar, S. (2018). Service innovation in times of economic crisis: the strategic adaptation activities of the top EU service firms. $R \& D$ Management, 48(2), 195-209. https://doi.org/10.1111/radm.12276

Mattsson, J., \& Orfila-Sintes, F. (2014). Hotel innovation and its effect on business performance. International Journal of Tourism Research, 16(4), 388-398. https://doi.org/10.1002/jtr.1933

Miles, I. (2005) Innovation in services. In J. Fagerberg, D. C. Mower and R. Nelson (Eds). The Oxford 
Handbook of Innovation, Oxford: Oxford University Press.

Miles, I. (2008). Patterns of innovation in service industries. IBM Systems Journal, 47(1), 115-128. DOI: $10.1147 /$ sj.471.0115

Miozzo, M., \& Soete, L. (2001). Internationalization of services: a technological perspective. Technological Forecasting and Social Change, 67(2), 159-185. https://doi.org/10.1016/S0040-1625(00)00091-3

Mortensen, P. S., \& Bloch, C. W. (2005). Oslo Manual-Guidelines for Collecting and Interpreting Innovation Data: Proposed Guidelines for Collecting and Interpreting Innovation Data. Organization for Economic Corporation and Development, OECD.

Nicolau, J., \& Santa-Maria, M. (2013). The effect of innovation on hotel market value. International Journal of Hospitality Management, 32, 71-79. https://doi.org/10.1016/j.ijhm.2012.04.005

Nieto, M. J., \& Santamaría, L. (2007). The importance of diverse collaborative networks for the novelty of product innovation. Technovation, 27(6-7), 367-377. https://doi.org/10.1016/j.technovation.2006.10.001

Nieto, M. J., \& Santamaría, L. (2010). Technological collaboration: Bridging the innovation gap between small and large firms. Journal of Small Business Management, 48(1), 44-69.

https://doi.org/10.1111/j.1540-627X.2009.00286.x

Nieves, J., Quintana, A., \& Osorio, J. (2014). Knowledge-based resources and innovation in the hotel industry. International Journal of Hospitality Management, 38, 65-73. https://doi.org/10.1016/j.ijhm.2014.01.001

Nieves, J., \& Segarra-Ciprés, M. (2015). Management innovation in the hotel industry. Tourism Management, 46, 51-58. https://doi.org/10.1016/j.tourman.2014.06.002

Orfila-Sintes, F., Crespí-Cladera, R., \& Martínez-Ros, E. (2005). Innovation activity in the hotel industry: Evidence from Balearic Islands. Tourism Management, 26(6), 851-865. https://doi.org/10.1016/j.tourman.2004.05.005

Orfila-Sintes, F., \& Mattsson, J. (2009). Innovation behavior in the hotel industry. Omega, 37(2), 380-394. https://doi.org/10.1016/j.omega.2007.04.002

Pavitt, K. (1984). Sectoral patterns of technical change: Towards a taxonomy and a theory. Research Policy, 13(6), 343-373. https://doi.org/10.1016/0048-7333(84)90018-0

Roberts, P. W., \& Amit, R. (2003). The dynamics of innovative activity and competitive advantage: The case of Australian retail banking, 1981 to 1995. Organization Science, 14(2), 107-122.

https://doi.org/10.1287/orsc.14.2.107.14990

Rodriguez, M., \& Camacho B.J. (2010). Are knowledge-intensive business services so "hard" innovators? Some insights using Spanish microdata. Journal of Innovation Economics \& Management, 5(1), 41-65. DOI 10.3917/jie.005.0041

Sandvik, I.L., Duhan, D.F., \& Sandvik, K. (2014). Innovativeness and profitability: An empirical investigation in the Norwegian hotel industry. Cornell Hospitality Quarterly, 55(2), 165-185. https://doi.org/10.1177/1938965514520963

Scaglione, M., Schegg, R., \& Murphy, J. (2009). Website adoption and sales performance in Valais' 
hospitality industry. Technovation, 29(9), 625-631. https://doi.org/10.1016/j.technovation.2009.05.011

Sharma, A., Motta, V.E.D., Choi, J.G., ... \& Altman, N.S. (2016). Economic production in hospitality and tourism industry: How do we compare to other services? International Journal of Contemporary Hospitality Management, 28(5), 1026-1050. https://doi.org/10.1108/IJCHM-07-2014-0316

Suoto, J.E. (2015). Business model innovation and business concept innovation as the context of incremental innovation and radical innovation. Tourism Management, 51, 142-155.

https://doi.org/10.1016/j.tourman.2015.05.017

Szczygielski, K., Grabowski, W., \& Woodward, R. (2017). Innovation and the growth of service companies: The variety of firm activities and industry effects. Industry and Innovation, 24, 249-262. https://doi.org/10.1080/13662716.2016.1232191

Tajeddini, K. (2010). Effect of customer orientation and entrepreneurial orientation on innovativeness: Evidence from the hotel industry in Switzerland. Tourism Management, 31(2), 221-231. https://doi.org/10.1016/j.tourman.2009.02.013

Tajeddini, K., Altinay, L., \& Ratten, V. (2017) Service innovativeness and the structuring of organizations: The moderating role of learning orientation and inter functional coordination. International Journal of Hospitality Management, 65, 100-114. https://doi.org/10.1016/j.ijhm.2017.06.010

Tavassoli, S., \& Karlsson, C. (2016). Innovation strategies and firm performance: Simple or complex strategies?. Economics of Innovation and New Technology, 25(7), 631-650. https://doi.org/10.1080/10438599.2015.1108109

Tether, B.S. (2005). Do services innovate (differently)? Insights from the European Innobarometer Survey. Industry and Innovation, 12(2), 153-184. https://doi.org/10.1080/13662710500087891

Tracey, J. B., \& Way, S. A. (2011). Making the most of your human capital. In M. C. Sturman, J. B. Corgel, \& R. Verma (Eds.), The Cornell School of Hotel Administration on hospitality: Cutting edge thinking and practice (pp. 444-554). New York, NY: Wiley. 


\section{FIGURES}

Sectoral variation

- KIBS, knowledge-intensive

- SIS, infrastructural

- SDS, supplier-dominated

- Hospitality and F\&B

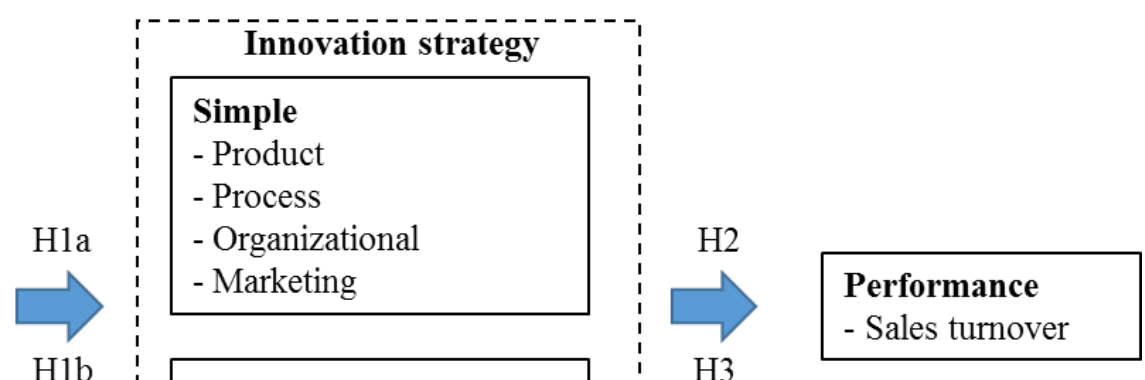

H3

Performance

Figure 1. Theoretical model and hypotheses.

- Technological

- Non-technological

- Hybrid

ybrid 


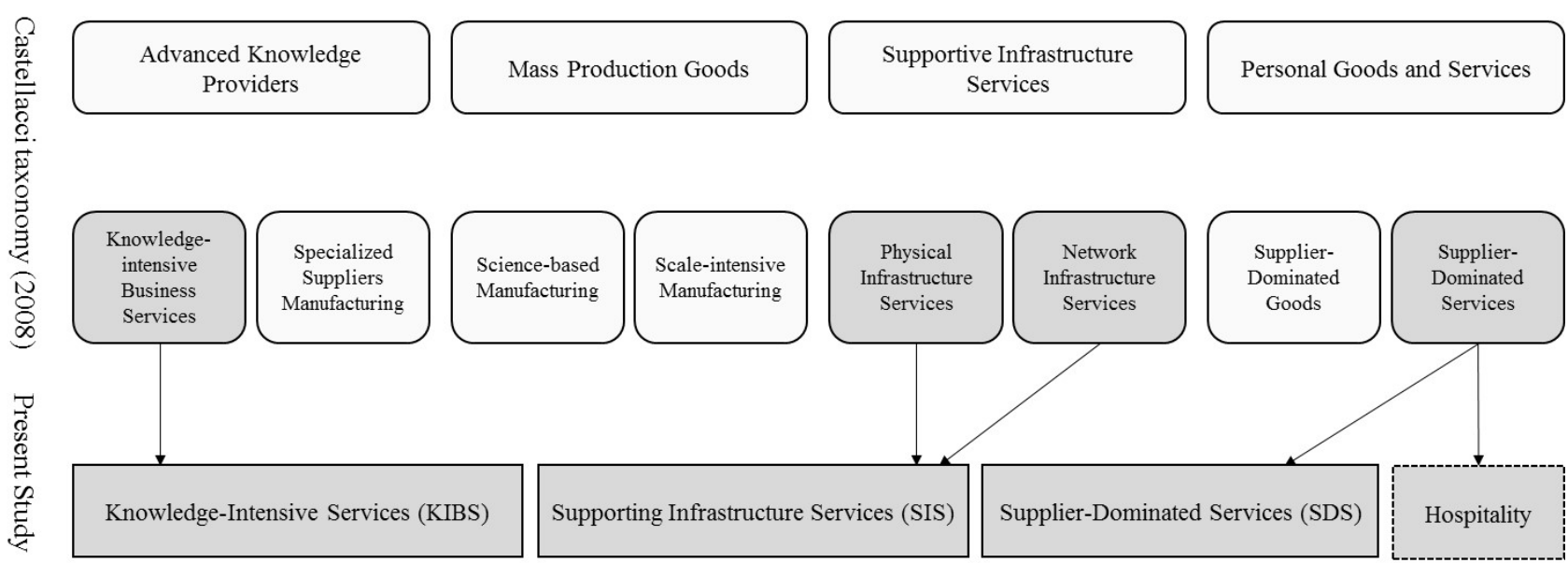

Figure 2. Service taxonomy. Groups of service (dark grey) and goods/manufacturing (light grey) in Castellacci taxonomy and this study

Source: Adapted from Castellacci (2008) 


\section{TABLES}

Table 1. Sectoral distribution of service firms according to Castellacci's taxonomy (2008)

\begin{tabular}{|c|c|c|c|}
\hline Taxonomy by Castellacci (2008) & Typical core sectors & NACE Code & Sample (\%) \\
\hline $\begin{array}{l}\text { Knowledge-Intensive Business } \\
\text { Services }\end{array}$ & $\begin{array}{l}\text { Computer programming, consultancy } \\
\text { Legal and accounting } \\
\text { Architectural and engineering } \\
\text { Advertising and market research } \\
\text { Other prof. and scientific activities } \\
\text { Prof., scientific, tech. Activities } \\
\text { Scientific. Research and veterinary } \\
\text { Employment activities } \\
\text { Travel agency and tour operator } \\
\text { Office admin., office support activities }\end{array}$ & $\begin{array}{l}62-63 \\
69-70 \\
71 \\
73 \\
74 \\
69-75 \\
72+75 \\
78 \\
79 \\
82\end{array}$ & 20.4 \\
\hline Supporting Infrastructure Services & $\begin{array}{l}\text { Wholesale trade } \\
\text { Land transport; transport via pipeline } \\
\text { Water transport } \\
\text { Transport activities } \\
\text { Air transport } \\
\text { Warehousing and supp. Activities } \\
\text { Post and courier activities } \\
\text { Support activities for transportation } \\
\text { Broadcasting, Video, Television, Music } \\
\text { Telecommunication } \\
\text { Financial service activities } \\
\text { Insurance activities } \\
\text { Activities auxiliary to fin. Services } \\
\text { Financial service activities } \\
\text { Real Estate activities } \\
\text { Rental and leasing activities } \\
\text { Services to buildings / landscape }\end{array}$ & $\begin{array}{l}46 \\
49 \\
50 \\
49-51 \\
51 \\
52 \\
53 \\
52-53 \\
59-60 \\
61 \\
64 \\
65 \\
66 \\
64-66 \\
68 \\
77 \\
81\end{array}$ & 48.1 \\
\hline Supplier-Dominated Services & $\begin{array}{l}\text { Water collection, treatment and supply } \\
\text { Waste management services } \\
\text { Waste management services } \\
\text { Construction services } \\
\text { Civil engineering services } \\
\text { Specialized+construction activities } \\
\text { Construction activities } \\
\text { Wholesale/Retail/Repair of motor vehicle } \\
\text { Retail except repair of motor vehicle } \\
\text { Wholesale/Retail/Repair of motor vehicle } \\
\text { Hospitality (F\&B activities) } \\
\text { Publishing activities } \\
\text { Security and investigation activities } \\
\text { Education } \\
\text { Human health activities } \\
\text { Residential care activities } \\
\text { Social work without accommodation } \\
\text { Cultural activities } \\
\text { Gambling and betting activities } \\
\text { Sports / recreation activities } \\
\text { Activities of membership org. } \\
\text { Repair of computers / personal goods } \\
\text { Other personal service activities }\end{array}$ & $\begin{array}{l}36 \\
36-39 \\
37-39 \\
41 \\
42 \\
43 \\
41-43 \\
45 \\
47 \\
45-47 \\
55-56 \\
58 \\
80 \\
85 \\
86 \\
87 \\
88 \\
90-91 \\
92 \\
93 \\
94 \\
95 \\
96\end{array}$ & 31.5 \\
\hline
\end{tabular}


Table 2. Items of the innovation types and control variables

\begin{tabular}{ll}
\hline Innovation Type & Item description \\
\hline Product (good) I. & $\begin{array}{l}\text { New or significantly improved goods (exclude the simple resale of new goods and changes of a } \\
\text { solely aesthetic nature) }\end{array}$ \\
Product (service) I. & New or significantly improved services. \\
Process I. 1 & New or significantly improved methods of manufacturing or producing goods or services.
\end{tabular}

Process I. 2

New or significantly improved logistics, delivery or distribution methods for your inputs, goods or services.

Process I. 3

New or significantly improved supporting activities for your processes, such as maintenance systems or operations for purchasing, accounting, or computing.

Organizational I. 1

New business practices for organizing procedures (i.e. supply chain management, business reengineering, knowledge management, lean production, quality management, etc.).

Organizational I. 2 New methods of organizing work responsibilities and decision making (i.e. first use of a new system of employee responsibilities, team work, decentralization, integration or de-integration of departments, education/training systems, etc.).

Organizational I. 3 New methods of organizing external relations with other firms or public institutions (i.e. first use of alliances, partnerships, outsourcing or sub-contracting, etc.).

Marketing I. 1

Significant changes to the aesthetic design or packaging of a good or service.

Marketing I. 2 New media or techniques for product promotion.

Marketing I. 3 New methods for product placement or sales channels.

Marketing I. $4 \quad$ New methods of pricing goods or services.

Company size

Country
$" 0 "=$ under 50 employees, " $1 "=50$ and more employees, " $2 "=50-249$ employees, " $3 "=250$ and more employees, " $4 "=250-499$ employees, " $5 "=500$ and more employees

$" 1 "=\mathrm{BG}, " 2 "=\mathrm{CY}, " 3 "=\mathrm{CZ}, " 4 "=\mathrm{DE}, " 5 "=\mathrm{EE}, " 6 "=\mathrm{ES}, " 7 "=\mathrm{HR}, " 8 "=\mathrm{HU}, " 9 "=\mathrm{LT}$, $" 10 "=$ NO, "11" = PT, "12" = RO, " $13 "=\mathrm{SI} ; " 14 "=\mathrm{SK}$

Source: Eurostat (2010) 
Table 3. Innovation strategies by service sector (total number of service firms: $\mathrm{N}=90896$ )

\begin{tabular}{|c|c|c|c|c|c|c|c|}
\hline & \multirow{2}{*}{ Type of Strategy } & \multirow{2}{*}{ Type of Innovation } & ALL & KIBS & SIS & SDS & Hospitality \\
\hline & & & \multicolumn{5}{|c|}{ Frequency [\%] } \\
\hline & \multirow{4}{*}{ Simple } & PROD & $2,195[2.4]$ & $951[5.3]$ & $760[1.7]$ & $458[1.8]$ & $32[1.1]$ \\
\hline & & PROC & $3,331[3.7]$ & $628[3.5]$ & $1,498[3.4]$ & $1,126[4.3]$ & $92[3.3]$ \\
\hline & & ORG & $5,701[6.3]$ & $1,279[7.1]$ & $2,371[5.3]$ & $1,971[7.5]$ & $115[4.1]$ \\
\hline & & MKT & $3,225[3.5]$ & $463[2.6]$ & $1,833[4.1]$ & $822[3.1]$ & $120[4.3]$ \\
\hline & \multirow{6}{*}{ Complex } & PROD_PROC ${ }^{\mathrm{a}}$ & $1,815[2.0]$ & $678[3.8]$ & $682[1.5]$ & $449[1.7]$ & $20[0.7]$ \\
\hline & & MKT_ORG ${ }^{b}$ & $4,230[4.7]$ & $420[4.0]$ & $2,172[4.9]$ & $1,205[4.6]$ & $154[5.5]$ \\
\hline & & PROD_MKT ${ }^{\mathrm{c}}$ & $799[0.9]$ & $267[1.5]$ & $380[0.9]$ & $147[0.6]$ & $10[0.4]$ \\
\hline & & PROD_ORG ${ }^{\mathrm{c}}$ & $907[1.0]$ & $469[2.6]$ & $259[0.6]$ & $175[0.7]$ & $9[0.3]$ \\
\hline & & PROC_MKT ${ }^{\mathrm{c}}$ & $621[0.7]$ & $94[0.5]$ & $293[0.7]$ & $202[0.8]$ & $33[1.2]$ \\
\hline & & PROC_ORG ${ }^{\mathrm{c}}$ & $2,482[2.7]$ & $595[3.3]$ & $950[2.1]$ & $898[3.4]$ & $53[1.9]$ \\
\hline \multirow[t]{6}{*}{ Hybrid } & & PROD_PROC_MKT & $899[1.0]$ & $271[1.5]$ & $415[0.9]$ & $208[0.8]$ & $16[0.6]$ \\
\hline & & PROD_PROC_ORG ${ }^{\mathrm{d}}$ & $2,016[2.2]$ & $861[4.8]$ & $669[1.5]$ & $506[1.9]$ & $6[0.2]$ \\
\hline & & PROD_MKT_ORG ${ }^{\mathrm{d}}$ & $1,268[1.4]$ & $505[2.8]$ & $505[1.1]$ & $246[0.9]$ & $23[0.8]$ \\
\hline & & PROC_MKT_ORG ${ }^{\mathrm{d}}$ & $2,002[2.2]$ & $369[2.1]$ & $974[2.2]$ & $614[2.3]$ & $68[2.4]$ \\
\hline & & PROD PROC_MKT_ORG ${ }^{\mathrm{d}}$ & $5,129[5.6]$ & $1,898[10.5]$ & $2,256[4.9]$ & $117[3.8]$ & $66[2.3]$ \\
\hline & & TOTAL INNOVATIVE FIRMS & $36,620[40.3]$ & $9,987[55.8]$ & $15,818[35.9]$ & $9,998[38.3]$ & $817[29.0]$ \\
\hline
\end{tabular}

Notes: PROD - product; PROC - process; ORG - organization; MKT - marketing; a - technological; b - non-technological; c - hybrid 2 innovations; $d$ - hybrid 3-4 innovations 
Table 4. The effects of innovation strategies on turnover performance in KIBS firms

\begin{tabular}{|c|c|c|c|c|c|c|c|}
\hline TURNOVER LN - KIBS & Model 1 & Model 2 & Model3 & Model 4 & Model 5 & Model 6 & Model 7 \\
\hline \multirow[b]{2}{*}{ Predictors } & \multirow[b]{2}{*}{ Control } & \multirow[b]{2}{*}{ Simple Innovations } & \multicolumn{4}{|c|}{ Complex Innovations } & \multirow{2}{*}{$\begin{array}{c}A L L \\
\text { innovations }\end{array}$} \\
\hline & & & Technological & Non-Technological & $\begin{array}{c}\text { Hybrid } \\
2 \text { innovations } \\
\end{array}$ & $\begin{array}{c}\text { Hybrid } \\
\text { 3-4 innovations }\end{array}$ & \\
\hline Country & $.05 * * *$ & $.05^{* * *}$ & $.05 * * *$ & $.05 * * *$ & $.05^{* * *}$ & $.05 * * *$ & $.05 * * *$ \\
\hline Company size & $.84 * * *$ & $.84 * * *$ & $.84 * * *$ & $.84 * * *$ & $.84 * * *$ & $.84 * * *$ & $.83 * * *$ \\
\hline PROD & & $.17 * * *$ & $.17 * * *$ & & & & $.32 * * *$ \\
\hline PROC & & $.15 * * *$ & $.16^{* * *}$ & & & & $.31 * * *$ \\
\hline ORG & & $.08^{*}$ & & .06 & & & $.24 * * *$ \\
\hline MKT & & $-.16 * *$ & & $-.18^{* * *}$ & & & -.008 \\
\hline PROD_PROC & & & $.18 * * *$ & & & & $.33 * * *$ \\
\hline MKT_ORG & & & & .02 & & & $.20 * * *$ \\
\hline PROD_MKT & & & & & $.23 * * *$ & & $.38 * * *$ \\
\hline PROD_ORG & & & & & $.25 * * *$ & & $.41 * * *$ \\
\hline PROC_MKT & & & & & -.009 & & .15 \\
\hline PROC_ORG & & & & & $.19 * * *$ & & $.35^{* * *}$ \\
\hline PROD_PROC_MKT & & & & & & .12 & $.24 * * *$ \\
\hline PROD_PROC_ORG & & & & & & $.34 * * *$ & $.47 * * *$ \\
\hline PROD_MKT_ORG & & & & & & $.25 * * *$ & $.37 * * *$ \\
\hline PROC_MKT_ORG & & & & & & $.25 * * *$ & $.37 * * *$ \\
\hline PROD_PROC_MKT_ORG & & & & & & $.22 * * *$ & $.34 * * *$ \\
\hline Adj $R^{2}$ & $.48 * * *$ & $.48 * * *$ & $.48 * * *$ & $.48 * * *$ & $.48 * * *$ & $.48 * * *$ & $.49 * * *$ \\
\hline$\Delta \mathbf{R}^{2}$ & & $.001 * * *$ & $.001 * * *$ & $.0 * * *$ & $.001 * * *$ & $.004 * * *$ & $.011 * * *$ \\
\hline $\mathbf{F}$ & $8235.12 * * *$ & $2,757.8 * * *$ & $3,309.97 * * *$ & $3,299.03 * * *$ & $2,758.34 * * *$ & $2,392.75 * * *$ & $1,012.24 * * *$ \\
\hline $\mathbf{N}$ & 17,887 & 17,887 & 17,887 & 17,887 & 17,887 & 17,887 & 17,887 \\
\hline
\end{tabular}


Table 5. The effects of innovation strategies on turnover performance in SIS firms

\begin{tabular}{|c|c|c|c|c|c|c|c|}
\hline TURNOVER LN - SIS & Model 1 & Model 2 & Model3 & Model 4 & Model 5 & Model 6 & Model 7 \\
\hline \multirow[b]{2}{*}{ Predictors } & \multirow[b]{2}{*}{ Control } & \multirow[b]{2}{*}{ Simple Innovations } & \multicolumn{4}{|c|}{ Complex Innovations } & \multirow{2}{*}{$\begin{array}{c}A L L \\
\text { innovations }\end{array}$} \\
\hline & & & Technological & Non-Technological & $\begin{array}{c}\text { Hybrid } \\
2 \text { innovations }\end{array}$ & $\begin{array}{c}\text { Hybrid } \\
\text { 3-4 innovations }\end{array}$ & \\
\hline Country & $.05^{* * *}$ & $.05 * * *$ & $.05 * * *$ & $.05^{* * *}$ & $.05^{* * *}$ & $.05^{* * *}$ & $.04 * * *$ \\
\hline Company size & $.87 * * *$ & $.87 * * *$ & $.87 * * *$ & $.87 * * *$ & $.87 * * *$ & $.84 * * *$ & $.82 * * *$ \\
\hline PROD & & $.46^{* * *}$ & $.46^{* * *}$ & & & & $.64 * * *$ \\
\hline PROC & & $.38 * * *$ & $.37 * * *$ & & & & $.56^{* * *}$ \\
\hline ORG & & $12 . * * *$ & & $.11 * * *$ & & & $.31 * * *$ \\
\hline MKT & & $.15^{* * *}$ & & $.13^{* * *}$ & & & $.32 * * *$ \\
\hline PROD_PROC & & & $.24 * * *$ & & & & $.43^{* * *}$ \\
\hline MKT_ORG & & & & $.16^{* * *}$ & & & $.36^{* * *}$ \\
\hline PROD_MKT & & & & & $.55 * * *$ & & $.43 * * *$ \\
\hline PROD_ORG & & & & & $.56^{* * *}$ & & $.74 * * *$ \\
\hline PROC_MKT & & & & & $.44 * * *$ & & $.76^{* * *}$ \\
\hline PROC_ORG & & & & & $.41 * * *$ & & $.63 * * *$ \\
\hline PROD_PROC_MKT & & & & & & $.44 * * *$ & $.36^{* * *}$ \\
\hline PROD_PROC_ORG & & & & & & $.69^{* * *}$ & $.58 * * *$ \\
\hline PROD_MKT_ORG & & & & & & $.59^{* * *}$ & $.83^{* * *}$ \\
\hline PROC_MKT_ORG & & & & & & $.62 * * *$ & $.76^{* * *}$ \\
\hline PROD_PROC_MKT_ORG & & & & & & $.83 * * *$ & $.98 * * *$ \\
\hline Adj $R^{2}$ & $.40 * * *$ & $.40 * * *$ & $.40 * * *$ & $.40 * * *$ & $.40 * * *$ & $.41 * * *$ & $.42 * * *$ \\
\hline$\Delta \mathbf{R}^{2}$ & & $.003 * * *$ & $.002 * * *$ & $.001^{* * *}$ & $.003^{* * *}$ & $.014^{* * *}$ & $.026 * * *$ \\
\hline $\mathbf{F}$ & $14,435.83 * * *$ & $4,864.94 * * *$ & $5,833.14 * * *$ & $5,789.96^{* * *}$ & $4,864.64 * * *$ & $4,370.36 * * *$ & $1,888.67 * * *$ \\
\hline $\mathbf{N}$ & 44,085 & 44,085 & 44,085 & 44,085 & 44,085 & 44,085 & 44,085 \\
\hline
\end{tabular}


Table 6. The effects of innovation strategies on turnover performance in SDS firms

\begin{tabular}{|c|c|c|c|c|c|c|c|}
\hline TURNOVER LN - SDS & Model 1 & Model 2 & Model3 & Model 4 & Model 5 & Model 6 & Model 7 \\
\hline \multirow{2}{*}{ Predictors } & \multirow[b]{2}{*}{ Control } & \multirow{2}{*}{ Simple Innovations } & \multicolumn{4}{|c|}{ Complex Innovations } & \multirow{2}{*}{$\begin{array}{c}A L L \\
\text { innovations }\end{array}$} \\
\hline & & & Technological & Non-Technological & $\begin{array}{c}\text { Hybrid } \\
2 \text { innovations }\end{array}$ & $\begin{array}{c}\text { Hybrid } \\
\text { 3-4 innovations }\end{array}$ & \\
\hline Country & $.04 * * *$ & $.04 * * *$ & $.04 * * *$ & $.05^{* * * *}$ & $.05 * * *$ & $.04 * * *$ & $.04 * * *$ \\
\hline Company size & $.78^{* * *}$ & $.12 * * *$ & $.77 * * *$ & $.87 * * *$ & $.78^{* * *}$ & $.77 * * *$ & $.75 * * *$ \\
\hline PROD & & $.12 * * *$ & $.12^{* * *}$ & & & & $.24 * * *$ \\
\hline PROC & & $.34 * * *$ & $.34^{* * *}$ & & & & $.46^{* * *}$ \\
\hline ORG & & $.03^{* * *}$ & & $.02 * * *$ & & & $.14 * * *$ \\
\hline MKT & & $.16^{* * *}$ & & $.16^{* * *}$ & & & $.27^{* * *}$ \\
\hline PROD_PROC & & & $.32^{* * * *}$ & & & & $.44 * * *$ \\
\hline MKT_ORG & & & & $.18^{* * *}$ & & & $.30^{* * *}$ \\
\hline PROD_MKT & & & & & .11 & & $23 * * *$ \\
\hline PROD_ORG & & & & & .001 & & $.13 * * *$ \\
\hline PROC_MKT & & & & & $.39 * * *$ & & $.51^{* * *}$ \\
\hline PROC_ORG & & & & & $.29^{* * *}$ & & $.42^{* * *}$ \\
\hline PROD_PROC_MKT & & & & & & $.38^{* * *}$ & $.47^{* * *}$ \\
\hline PROD_PROC_ORG & & & & & & $.43^{* * *}$ & $.54 * * *$ \\
\hline PROD_MKT_ORG & & & & & & $.19^{* * *}$ & $.29 * * *$ \\
\hline PROC_MKT_ORG & & & & & & $.49 * * *$ & $.59 * * *$ \\
\hline PROD_PROC_MKT_ORG & & & & & & $.38 * * *$ & $.48 * * *$ \\
\hline Adj $R^{2}$ & $.42^{* * * *}$ & $.43^{* * *}$ & $.43 * * *$ & $.40^{* * *}$ & $.43^{* * *}$ & $.43 * * *$ & $.44^{* * *}$ \\
\hline$\Delta \mathbf{R}^{2}$ & & $.002 * * *$ & $.002 * * *$ & $.001 * * *$ & $.001 * * *$ & $.005 * * *$ & $.013 * * *$ \\
\hline $\mathbf{F}$ & $9,610.86^{* * *}$ & $3,229.74 * * *$ & $3,881.12 * * *$ & $3,855.64 * * *$ & $3,222.15^{* * *}$ & $2,806.25^{* * *}$ & $1,192.88^{* * *}$ \\
\hline $\mathbf{N}$ & 26,108 & 26,108 & 26,108 & 26,108 & 26,108 & 26,108 & 26,108 \\
\hline
\end{tabular}


Table 7. The effects of innovation strategies on turnover performance in hospitality firms

\begin{tabular}{|c|c|c|c|c|c|c|c|}
\hline TURNOVER LN - HOSP & Model 1 & Model 2 & Model3 & Model 4 & Model 5 & Model 6 & Model 7 \\
\hline \multirow[b]{2}{*}{ Predictors } & \multirow[b]{2}{*}{ Control } & \multirow[b]{2}{*}{ Simple Innovations } & \multicolumn{4}{|c|}{ Complex Innovations } & \\
\hline & & & Technological & Non-Technological & $\begin{array}{c}\text { Hybrid } \\
2 \text { innovations } \\
\end{array}$ & $\begin{array}{c}\text { Hybrid } \\
\text { 3-4 innovations } \\
\end{array}$ & innovations \\
\hline Country & $-.16 * * *$ & $-.16^{* * *}$ & $-.16^{* * *}$ & $-.16^{* * *}$ & $-.17 * * *$ & $-.23 * * *$ & $-.26 * * *$ \\
\hline Company size & $.79 * * *$ & $.79 * * *$ & $.78^{* * *}$ & $.78^{* * *}$ & $.78 * * *$ & $.77 * * *$ & $.76^{* * *}$ \\
\hline PROD & & -.25 & -.25 & & & & -.17 \\
\hline PROC & & .08 & .07 & & & & .16 \\
\hline ORG & & .04 & & .04 & & & .11 \\
\hline MKT & & -.009 & & -.004 & & & .07 \\
\hline PROD_PROC & & & .01 & & & & .12 \\
\hline MKT_ORG & & & & .07 & & & .14 \\
\hline PROD_MKT & & & & & .24 & & .28 \\
\hline PROD_ORG & & & & & $.66^{*}$ & & $.73 * *$ \\
\hline PROC_MKT & & & & & $.40 * *$ & & $.48^{* * *}$ \\
\hline PROC_ORG & & & & & $.44 * * *$ & & $.51 * * *$ \\
\hline PROD_PROC_MKT & & & & & & $.97 * * *$ & $1.03 * * *$ \\
\hline PROD_PROC_ORG & & & & & & $.96 * * *$ & $1.03 * *$ \\
\hline PROD_MKT_ORG & & & & & & $.38 *$ & $.43^{*}$ \\
\hline PROC_MKT_ORG & & & & & & .28 & $.33 * *$ \\
\hline PROD_PROC_MKT_ORG & & & & & & $.59 * * *$ & $.64 * * *$ \\
\hline $\operatorname{Adj} R^{2}$ & $.67 * * *$ & .67 & .67 & .67 & $.67 * * *$ & $.67 * * *$ & $.68 * * *$ \\
\hline$\Delta \mathbf{R}^{2}$ & & .0 & .0 & .0 & $.003 * * *$ & $.007 * * *$ & $.012 * * *$ \\
\hline $\mathbf{F}$ & $2,808.65^{* * *}$ & $936.67 * * *$ & $1,124.27 * * *$ & $1,123 * * *$ & $957.57 * * *$ & $827.99 * * *$ & $347.33 * * *$ \\
\hline $\mathbf{N}$ & 2,816 & 2,816 & 2,816 & 2,816 & 2,816 & 2,816 & 2,816 \\
\hline
\end{tabular}


